\title{
CITIZENSHIP, NATIONAL IDENTITY, AND THE SEARCH FOR STABILITY IN CANADA
}

\section{RAYMOND BLAKE}

UNIVERSITY OF REGINA, UNIVERSITY COLLEGE DUBLIN

\begin{abstract}
When Canada was created it debated if it was best to seek political solidarity by creating a single political identity or was it wiser to build a citizenship that made space for all communities. This article argues there was no attempt to unite Canadians around a single national loyalty but only to join an array of diverse communities whose members might adopt a shared citizenship. Since 1867, Canada has adopted different approaches to creating citizenship to maintain political solidarity. Diversity has been an integral part of that narrative.

Keywords: Canada; diversity; citizenship; nation-building; George-Étienne Cartier; Justin Trudeau DOI: $10.14712 / 23363231.2020 .2$
\end{abstract}

\section{Introduction}

Many Canadians believe their country is an inclusive nation and diversity is one of the characteristics that define them. They might even argue that diversity has been a permanent fixture of Canada since Europeans began to settle in North America. The search for accommodation between the descendants

The research for this article was supported by an Insight Grant from the Social Sciences and Humanities Research Council of Canada and the Craig Dobbin Professorship of Canadian Studies at University College Dublin.

Dr. Raymond Blake is a professor of history at the University of Regina, Saskatchewan, and Craig Dobbin Professor at University College Dublin for 2019-2020. Address correspondence to University of Regina - History Department, 3737 Wascana Parkway, Regina, SK S4S 0A2, Canada. E-mail: Raymond.Blake@uregina.ca.

The author wishes to thank the two anonymous readers who offered excellent suggestions for revisions during the peer-review process. 
of early British and French-speaking settlers began in earnest in the mid-eighteenth century after France ceded much of what would become Canada to the British and the two ethnic groups, often warring against each other with their Indigenous allies in the past, realized they had little choice but to work collaboratively. By the middle of the nineteenth century they had established a level of cooperation that led, first, to responsible government in 1848 and, then, to Confederation in 1867, even though Lord Durham, who was appointed governor of British territory in North America following the rebellions of 1837 and 1838, had called for the assimilation of French Canada into the dominant British paradigm. ${ }^{1}$ Various ethnic groups, notably those that came from Europe in the nineteenth and twentieth centuries, were accommodated into a Canadian mosaic in the decades that followed but it was much later before Indigenous peoples and First Nations were considered part of Canada's founding peoples. Yet, Canadians have long celebrated their commitment to diversity and inclusion, and successive prime ministers have been engaged since 1867 in the construction of a series of national narratives to foster a citizenship that embraces the various diverse political and cultural communities that constitute Canada. While the search for the accommodation of most ethnic groups and a citizenship inclusive of all diverse communities have been ongoing since Canada was founded, the attempts to create a cohesive nation continue to face great challenges. Recent census data show that more than 7.5 million Canadians, representing nearly 22 percent of the population, are foreign-born. In the country's two largest cities, Toronto and Vancouver, newcomers represent 46.1 and 40.8 percent of the population, respectively. ${ }^{2}$ Several opinion polls throughout 2019 found that attitudes towards immigration may be hardening as three-quarters of Canadians expressed fears that the country may be reaching a limit in its ability to successfully integrate newcomers. ${ }^{3}$ A recent survey by Environics Institute also found that while the nation is important to Canadians' personal sense of identity, it is other identities, such as region or province, language, ethnicity or race, and gender, that is of growing importance to individual identity. Still, the survey

1 See John Ralston Saul, Extraordinary Canadians: Louis Hippolyte LaFontaine and Robert Baldwin (Toronto: Penguin, 2012) on the 1840s. Saul argued that LaFontaine and Baldwin laid the foundations of a new nation with a "broad program of social, political, economic and administrative policies consciously and intellectually designed to bring together opposing religions, languages and races."

2 "Immigration and Ethnocultural Diversity: Key Results from the 2016 Census," Statistics Canada, October 25, 2017, https://www150.statcan.gc.ca/n1/daily-quotidien/171025/dq171025b-eng.htm.

3 See, for example, Teresa Wright, "Majority of Canadians think immigration should be limited: poll," Global News, June 16, 2019, https://globalnews.ca/news/5397306/canada-immigration-poll. 
found that Canadians continue to share similar values but their confidence in the nation's capacity to resolve differences and fragmentation that exist is much lower than it was in a generation ago. ${ }^{4}$

This article shows how successive governments and prime ministers have attempted to manage diversity and build a citizenship narrative that is inclusive and sustains the fragile Canadian state. It examines, in other words, how the Canadian state has, since 1867, attempted to create a sense of belonging or an "imagined community" in the words of Benedict Anderson. ${ }^{5}$ It argues that prime ministers have embraced Canada's diversity in their speeches and other public pronouncements while encouraging all Canadians to share a common sense of citizenship based on a shared purpose and shared values. ${ }^{6}$ In this article, citizenship is considered to mean the system of values, institutional practices, and narratives that provide the conditions that allow for individuals and groups to belong to, or be members of, a national community and live together in relative harmony in an increasingly complex society. ${ }^{7}$ Much of the historiography on national identity, citizenship and nationalism in Canada has been preoccupied with how the Canadian state replaced its ethnic nationalism, based largely on a dual British and French heritage, with a civic nationalism in the 1970s and 1980s that included a Charter of Rights and Freedoms, an official languages act, and a policy of official multiculturalism that, collectively, came to define what it meant to be Canadian. ${ }^{8}$ This process, it has been argued, asked citizens to believe there was no dominant ethnic culture; rather, Canadians could celebrate the

4 “2019 Survey of Canadians. Canada: Pulling Together or Drifting Apart. Final Report, April 2019” (Study conducted by the Environics Institute for Social Research), https://www.environicsinstitute .org/docs/default-source/project-documents/confederation-of-tomorrow-2019-survey---report -1/confederation-of-tomorrow-survey-2019---report-1-pulling-together-or-drifting-apart---final -report.pdf.

5 Benedict Anderson, Imagined Communities: Reflections on the Origin and Spread of Nationalism (London: Verso, 1991).

6 On this point, see Samuel V. LaSelva, The Moral Foundations of Canadian Federalism: Paradoxes, Achievements, and Tragedies of Nationhood (Montreal / Kingston: McGill-Queen's University Press, 1996).

7 Georgi Dimitrov and Pepka Boyadieva, "Citizenship Education as an Instrument for Strengthening the State's Supremacy: An Apparent Paradox?” Citizenship Studies 13, No. 2 (2009): 153-169, doi: $10.1080 / 13621020902731165$.

8 See Jatinder Mann, The Search for a New National Identity: The Rise of Multiculturalism in Canada and Australia, 1890s-1970s (New York: Peter Lang, 2016); Michael Ignatieff, The Rights Revolution (Toronto: Anansi, 2000); Will Kymlicka, Finding Our Way: Rethinking Ethnocultural Relations in Canada (Don Mills, ON: Oxford University Press, 1998); and Charles Taylor, Reconciling the Solitudes: Essays on Canadian Federalism and Nationalism (Montreal / Kingston: McGill-Queen's University Press, 1993). 
triumph of diversity which recognized the same rights for all Canadians regardless of their ethnicity while repudiating the two-nation narrative in favor of official multiculturalism while, yet, continuing to embrace the Canadian values of the rule of law, the equality of women and men, democracy and other values common to most liberal, democratic states. ${ }^{9}$ This article contends that the search to bridge the diversity factor is not new. It shows that prime ministers, at the time of Confederation and since, have sought to construct an inclusive national identity and a citizenship narrative that would build social and political solidarity and social cohesion and stability by not only recognizing Canada's diversity but by embracing it. Their attempts have taken various forms since 1867, and it is important to understand that the narrative of multiculturalism and rights is only one of many narratives constructed by political leaders to build an inclusive citizenship in Canada. As such, this article contributes to the debate on Canadian national identity and citizenship by showing that the Canadian state has long struggled with how best to build a national community that accommodates and recognizes the diversity that has always been the Canadian reality.

\section{Notions of Belonging at Confederation, 1867}

Since Canada's founding in 1867, politicians have been concerned with how to achieve social harmony and cohesion among its diverse and multiethnic foundations and how to foster a sense of belonging for all citizens. There had been no attempt in 1867 to unite Canadians around a single national loyalty but only to join an array of communities whose members might possibly become a single united people under a national government and remain loyal to that state. ${ }^{10}$ The political leaders who negotiated the creation of Canada in the 1860s wrestled with the most important question that leaders of all nation-states with diverse populations must ask - is it best to seek national unity and political solidarity by trying to create a single, dominant political identity, or is it wiser to build a national identity that makes space for, and accepts, the legitimacy of all of the communities that comprise the nation. They concluded the latter was the best path forward and included in Canada's constitution the necessary elements to

9 Jose E. Igartua, The Other Quiet Revolution: National Identities in English Canada, 1945-1971 (Vancouver: University of British Columbia Press, 2007); and Mann, The Search for a New National Identity.

${ }^{10}$ Robert C. Vipond, Liberty and Community: Canadian Federalism and the Failure of the Constitution (Albany, NY: State University of New York Press, 1991), 4 and 47-82. 
create a sense of belonging. ${ }^{11}$ They regarded the acceptance of pluralism and diversity-based linguistic and cultural rights as essential to Canadian unity. The country aspired to inter-societal reconciliation rather than the vanquishing of minority communities. ${ }^{12}$ The hope was that a political rather than ethnic approach to citizenship would lead to a sense of belonging among the various communities that constituted the nation.

Diversity, then, became a virtue in the new political order that was created and it can be seen in the constitution that was enacted in 1867. Two of the important architects in that process were John A. Macdonald, who became Canada's first prime minister, and his long-time, French-speaking and Catholic ally, George-Étienne Cartier. They held different views of what Canada should be, but the British North America Act incorporated the vision and values of both. Macdonald dreamed of an economic union as the foundation of effective nationhood and maintained that the national government required a variety of general powers and overarching authorities to supervise the provinces to do so. Cartier, on the other hand, insisted that Canada accommodate its distinct minorities. He understood that a series of geopolitical, economic and historical realities meant that by 1867 two settler communities - one French-speaking and the other English - were firmly entrenched, and if the new nation were to succeed the constitution had to prevent the national majority from annexing the French minority that was already very much a part of Canada's cultural identity. ${ }^{13}$ For Cartier, diversity was a fact that could not be erased from the Canadian polity, and it had to be reconciled to achieve unity. In British North America, he said, "we are five different peoples [English, Scottish, Welsh, Irish, and French] living in five separate provinces," and with Confederation, they would form "a political nationality independent of national origin, or the religion of any one individual." ${ }^{14}$ Macdonald himself echoed those sentiments: "We have a constitution now under which all British subjects are in a position of absolute equality, having

${ }^{11}$ Some of those ideas are developed in John D. Whyte, "Federalism Dreams," Queen's Law Journal 34 (2008): 1-24.

12 Some will take issue with this claim and point to the Canada's treatment of Indigenous peoples as an example of genocide. See James Daschuk, Clearing the Plains: Disease, Politics of Starvation and the Loss of Aboriginal Life (Regina: University of Regina Press, 2013); and Andrew Woolford and Jeff Benvenuto, “Canada and Colonial Genocide," Journal of Genocide Research 17, No. 4 (2015): 373-390, doi: 10.1080/14623528.2015.1096580.

${ }^{13}$ For the differences between John A. Macdonald and George-Étienne Cartier, see A. I. Silver, The French-Canadian Idea of Confederation 1864-1900 (Toronto: University of Toronto Press, 1982), $36-38$.

14 Canada, Parliamentary Debates on the subject of the Confederation (Quebec: Hunter Rose, 1865), $55-59$. 
equal rights of every kind - of language, of religion, of property and of person. There is no paramount race in this country." 15 Their hope was that Indigenous peoples would be assimilated and assume the attributes of Europeans.

Cartier's dream for Canada was crucial in creating a sense of belonging, and it is evident not only in the constitutional recognition of Canada's religious, linguistic and legal duality but also in its federal constitution. Federalism was adopted to share responsibility between competing provincial and national interests and to find balance between unity and diversity while providing a design for social cohesion and, at the same time, forging a framework for a national economy. ${ }^{16}$ The division of powers inherent in the federation was a legal recognition of the diversity that existed among the initial members of Confederation, and Cartier insisted that it was the political mechanism by which diversity could be reconciled with unity. Cartier said it "protects the rights and privileges of the minority and the majority." 17 He reassured his French-speaking constituency that the federal arrangement posed "no danger to the rights of French Canadians, Scotchmen, Englishmen or Irishmen." "I8 "In our own Federation," Cartier said, "we [will] have Catholic and Protestant, English, French, Irish and Scotch, and each by his efforts and his success [will] increase the prosperity and glory of the new Confederacy [...] we [are] of different races, not for the purpose of warring against each other, but in order to compete and emulate for the general welfare." ${ }^{19}$ For him, Canada created a single political or civic nationality but one where multiple and diverse cultural identities and multiple allegiances could develop and flourish. ${ }^{20}$

Canada would be a modern nation where neither the national origin, nor the religion of any individual would matter. The strength of the new nation came from its diversity and all people would belong, shape and define the national identity. Diversity was the Canadian ideal, and Cartier believed that all Canadians would want to protect the rights of minorities which was in many ways

15 House of Commons Debates, 6th Parliament, 4th Session (January 16, 1890 to May 16, 1890), Vol. 1, 745.

16 La Minerve, April 13, 1853, quoted in Alastair C. F. Gillespie, George-Étienne Cartier. The Canadian (Toronto: Macdonald-Laurier Institute, 2017), 8.

17 “The Rights of Each and Every Citizen Will Be Protected,” Speech by George-Étienne Cartier, May 17, 1867, https://www.macdonaldlaurier.ca/the-rights-of-each-and-every-citizen-will-be -protected-may-17-1867-speech-by-george-etienne-cartier.

18 Quoted in Allan Smith, Canada. An American Nation? Essays on Continentalism, Identity, and the Canadian Frame of Mind (Montreal / Kingston: McGill-Queen's University Press, 1994), 135.

19 Cited in the Parliamentary Debates on the subject of the Confederation (1865), 60; Reference re Secession of Quebec [1998] 2 S.C.R. 217.

${ }^{20}$ LaSelva, The Moral Foundations, 34-38. 
a new modern approach to citizenship and nation-building. Cartier believed that bringing together diverse peoples - as he understood diversity - would allow each group to contribute to the social, economic and cultural success of Canada. ${ }^{21}$ Unfortunately, neither Macdonald nor Cartier paid much attention to Indigenous peoples except to continue the assimilative policies of colonial Canada as a way of achieving their full integration into Canadian society.

\section{The Cartier Dream is Challenged}

The Canada that was constructed in the decades after Confederation failed to live up to the dreams of diversity and belonging that held such promise in 1867. It seemed at times, though, that Cartier's dream might prevail. When Manitoba was added to the federation, the linguistic and cultural duality of that province was acknowledged in the Manitoba Act of 1870. The recognition of the acceptance of diversity was also evident in Treaty 8 , negotiated in the summer of 1899 with the Wood Cree, the Beaver and the Chipewyans in western Canada. Like other Numbered Treaties, it was designed to acquire First Nations' territory for European settlement, but it also gave full consent to First Nations' requests that their economic and cultural practices continue. Canadian criminal law was to apply to all, including First Nations, but Canadian and First Nations leaders reconciled competing interests to accommodate and protect existing political communities. First Nation leaders received exemption from the most onerous obligations of citizenship (taxation and conscription), social benefits, and other measures to preserve their religious and cultural integrity. ${ }^{22}$ Canada was struggling to build a political community based on a common citizenship with specific obligations and entitlements while recognizing and accommodating distinct political identities, and although some of the Numbered Treaties attempted to maintain some cultural integrity around Indigenous communities, Canada put in place a series of colonial structures to marginalize and assimilate Indigenous peoples. Justice Murray Sinclair, chair of the Truth and Reconciliation Commission, and others have accused the Canadian government of "cultural genocide" in its dealing with Indigenous peoples after Confederation. ${ }^{23}$

${ }^{21}$ Quoted in Christopher Moore, 1867. How the Fathers Made a Deal (Toronto: McClelland and Stewart, 1997), 233.

22 Whyte, "Federalism Dreams."

${ }^{23}$ SeeBeverleyMcLachlin, "DefiningMoments: The Canadian Constitution”(DicksonLecture delivered on February 13, 2014), https://www.scc-csc.ca/judges-juges/spe-dis/bm-2014-02-13-eng.aspx. 
Even if Canada recognized diversity as a way of creating a sense of belonging in the first decades of Confederation, the implementation of the Treaties, for instance, failed to accommodate differences between Indigenous peoples and other Canadians largely because notions of citizenship and the sense of belonging in Canada faced challenges posed by new social and political dynamisms as the country's population grew and changed. When Canada put aside its original ideal of diversity and inclusion, it led invariably to instability and disorder in many minority communities while the Indigenous communities are the most seriously affected. Canada subsequently has had a contentious history with its various minority communities, especially in the late nineteenth and early twentieth centuries, and had at times an abhorrent human rights' record, especially against its Indigenous peoples but other minorities, too. The legacy of colonialism and the litany of misguided and harmful government policies towards Indigenous communities have had devastating consequences. Those policies, including the dispossession of Indigenous lands, the imposition of a paternalistic Indian Act, the devastating impact of residential schools that separated children from their parents and their culture, the forced relocation of Inuit and First Nation communities, and the state-sanctioned adoption of Indigenous children by white families well into the 1960 s, have created considerable damage that is still evident today. ${ }^{24}$

The perniciousness of colonialism has left an indelible mark on Indigenous peoples, who have a standard of living and health and educational outcome far below the national average, and a blight on the Canadian state. The World Health Organization's research into health determinants has established European colonization as a fundamental and underlying determinant of poor health, including higher risk for earlier death than non-Indigenous peoples, and higher rates of chronic ailments such as diabetes and heart disease. Canada's colonial approach to education for First Nations' communities through Indian Residential Schools have had a devastating and demoralizing legacy that continues to wreak havoc in many Indigenous communities that are often marked with high rates of unemployment, alcoholism, violence and suicide. Too many reserves have inadequate housing and undrinkable water, and recent statistics show that while Indigenous peoples constitute less than 4 percent of the population they account for 25 percent of those incarcerated in federal correctional services. Indigenous

\footnotetext{
${ }^{24}$ For Canada's treatment of Indigenous peoples, see John Borrows, "Questioning Canada's Title to Land," in Recovering Canada: The Resurgence of Indigenous Law (Toronto: University of Toronto Press, 2002); and J. R. Miller, Residential Schools and Reconciliation (Toronto: University of Toronto Press, 2017).
} 
demands for power-sharing as a third order of government have either been dismissed or ignored. Indigenous leaders and activists are increasingly disaffected as promises of reconciliation and improved state-Indigenous relations have not materialized. ${ }^{25}$

In the early years of Confederation, there was, moreover, considerable anti-French and anti-Catholics sentiment that also threatened Canadian unity if not the nation itself. The Canada First Movement, created shortly after Confederation, sought greater Canadian independence from Great Britain but it also promoted Anglo-Saxon values and institutions as the way to full Canadian nationhood. Like the Orange Order that also emerged as an influential Protestant organization in the late nineteenth century, it rejected French Canadian nationalism and created serious moments of racial and ethnic conflict. The French-speaking community in much of English-speaking Canada has faced considerable opposition and a serious assault on language rights and religious schooling, especially in New Brunswick, Ontario, and throughout Western Canada. ${ }^{26}$ In Quebec, meanwhile, some nationalists like Abbe Lionel Groulx, the editor of the Montreal magazine L'Action française, proposed in 1922 the creation of Laurentie, a country separate from Canada. ${ }^{27}$ As well, a number of other minorities have also been victims of the Canadian state, notably, Ukrainians, Germans, and Japanese during wartime, and other immigrant communities, including South Asians, Jews, and Chinese. ${ }^{28}$ Moreover, there was little tolerance for those who criticized norms, such as liberal democracy, capitalism, patriarchy, and traditional marriage and traditional families. The political left was often regarded as treasonous Communists, and many citizens found themselves isolated because of their ethnicity, gender, or sexual orientation. Indigenous

\footnotetext{
25 Salmaan Farooqui, "UN report highlights 'abhorrent' housing conditions for Indigenous people," CTV News, October 21, 2019, https://www.ctvnews.ca/canada/un-report-highlights-abhorrent -housing-conditions-for-indigenous-people-1.4647433; Amanda Coletta, “"Third World conditions': Many of Canada's indigenous people can't drink the water at home," The Washington Post, October 15, 2018, https://www.washingtonpost.com/world/the_americas/third-world-conditions -many-of-canadas-indigenous-people-cant-drink-the-water-at-home/2018/10/14/c4f429b4-bc53 -11e8-8243-f3ae9c99658a_story.html; James Anaya, "Report of the Special Rapporteur on the rights of Indigenous peoples: The situation of indigenous peoples in Canada," July 4, 2014, http:// unsr.jamesanaya.org/country-reports/the-situation-of-indigenous-peoples-in-canada.

${ }^{26}$ Carl Berger, "The True North Strong and Free," in Nationalism in Canada, ed. Peter Russell (Toronto: McGraw-Hill, 1966), 3-26.

${ }^{27}$ Réal Bélanger, "Henrie Bourassa," in Dictionary of Canadian Biography, Vol. 18 (Toronto / Laval: University of Toronto / Université Laval, 2009), http://www.biographi.ca/en/bio/bourassa_henri 18E.html.

${ }_{28}$ Ninette Kelley and M. J. Trebilcock, The Making of the Mosaic: A History of Canadian Immigration Policy (Toronto: University of Toronto Press, 2010).
} 
peoples, women, youth and those considered "other" were expected to know their place, accept their historical roles, and behave within accepted norms even if they chafed under the constraints placed upon them. For much of Canada's existence, especially prior to the end of the Second World War, the state demonstrated little interest in protecting and promoting linguistic and cultural diversity outside of Quebec despite the continuing national narrative of accommodating diversity and including all political and cultural communities in the nation. That it did not do so raised serious questions of belonging among many Canadians.

\section{A Second Narrative of Citizenship and Belonging, Post-1945}

After the Second World War, the Canadian Government believed that a new national narrative and a new sense of identity were needed to reinforce social cohesion, rebuild national unity and foster a sense of belonging in Canada. The battle over conscription, especially, had split the country largely along linguistic lines, with English-speaking Canadians in favor and French-speaking opposed. It had not only shattered national unity but threatened the very survival of Canada. Added to the nation's unity woes were regional conflicts, the growing unrest of labor and the rise of the political left, and the emergence of new nationalist movements, particularly in Quebec and among Indigenous peoples. When the war had turned in the Allies' favor, the Canadian government introduced a series of initiatives to foster a greater sense of Canada's distinct identity to win support in Quebec and create a stronger sense of belonging among most Canadians that had been shaken by years of economic depression and war. A series of British symbols, such as British citizenship itself, the Red Ensign flag, and words, such as "Dominion" and "Her Majesty's" - all associated with Canada's colonial history - had to be eradicated, although the process would take a generation to complete. ${ }^{29}$ Institutionalized British symbols, many believed, had created a trauma that had prevented non-English-speaking Canadians from embracing a Pan-Canadian national identity. In short order, the government drew up plans for a new citizenship act, a distinctive Canadian flag, and the replacement of the word "Dominion" in various government agencies and state-sponsored activities. Over the ensuing two decades, Canadians mostly embraced attempts to foster a stronger Canadian nationalism and an inclusive national identity. ${ }^{30}$ The adoption of

\footnotetext{
${ }^{29}$ Allan Sears, "Instruments of Policy: How the Federal State Influences Citizenship Education in Canada," Canadian Ethnic Studies 29, No. 2 (1997): 1-21.

${ }^{30}$ Halifax Chronicle, June 20, 1946.
} 
a new distinctive flag - the maple leaf - was perhaps the most contested of the process of remaking the national identity and fostering a greater sense of belonging but it has become one of the most popular symbols of Canada. ${ }^{31}$

The reshaping of Canada and the promotion of a greater sense of belonging also included the expansion of social rights. This ambitious period of federal social reconstruction not only altered the role of the federal government but also Canadians' notion of citizenship and identity. They no longer saw themselves as simply citizens of a particular national, political or cultural community but as citizens entitled to certain social and material rights by virtue of being Canadian. Their sense of national identity and citizenship was reconstructed with the introduction of social security initiatives that blossomed within the Keynesian economic framework. It provided, notably, unemployment insurance, family allowances and veterans' benefits during the Second World War, followed shortly after with a number of other programs that further helped to sustain economic growth and maintain full employment. It also transformed the relationship between citizen and state. Prime Minister Mackenzie King believed that a set of social rights, shared by and available to all citizens, would enhance a sense of community, build social cohesion, and restore national unity as well as safeguard the existing capitalist system and maintain the existing social order. The redistributive nature inherent in social programs fostered a national identity that strengthened the level of attachment of citizens to the nation and encouraged them to see themselves as members of a single community, enjoying a common set of rights while sharing common obligations to each other and to the state..$^{32}$ Canadians subsequently became one of a few peoples around the world to regard their social security state as a defining national characteristic. ${ }^{33}$

${ }^{31}$ On the flag, see C. P. Champion, "A Very British Coup: Canadianism, Quebec, and Ethnicity in the Flag Debate, 1964-1965," Journal of Canadian Studies / Revue d'études canadiennes 40, No. 3 (2006): 68-99. This article argues that the identity debate about the flag was far more complex than is commonly perceived.

32 On this point see, T. H. Marshall, Citizenship and Social Class and Other Essays (Cambridge: Cambridge University Press, 1950); Raymond B. Blake, From Rights to Needs: A History of Family Allowances in Canada, 1929-1992 (Vancouver: UBC Press, 2009); Keith Banting, "Social Citizenship and the Multicultural Welfare State," in Citizenship, Diversity, and Pluralism, ed. Alan C. Cairns, John C. Courtney, Peter MacKinnon, Hans J. Michelmann, and David E. Smith (Montreal / Kingston: McGill-Queen’s University Press, 1999), 108-136; and Janine Brodie, "Citizenship and Solidarity: Reflections on the Canadian Way," Citizenship Studies 6, No. 4 (2002): 377-394.

33 On this point, see Richard Johnston, Keith Banting, Will Kymlicka, and Stuart Soroka, "National Identity and Support for the Welfare State," Canadian Journal of Political Science 43, No. 2 (2010): 349-377. 
From the Second World War to the mid-1960s, then, a new social citizenship and a new national identity became the primary basis for creating a sense of belonging among Canadians and restoring Canada's initial commitment to diversity. There were also attempts at constitutional reform to better reflect Canada's diversity but they largely proved unsuccessful. The government appointed a Royal Commission on Bilingualism and Biculturalism in 1963 as a response to the growing unrest among French-speaking Canadians, especially in Quebec, who called for better protection of their language and culture and for opportunities to participate more fully in political and economic decision making. Canada also embraced what has become known as cooperative or asymmetrical federalism to describe the government's attempt to reach some level of accommodation with the ten provinces by allowing the national government to work out separate arrangements with different provinces on a variety of policy matters from immigration to public pensions that gave certain powers to some that others might not enjoy. The state also used its authority to address regional grievances and build social cohesion through a range of policies such as preferential freight rates for farmers, economic development strategies for particular regions, and protection for particular industries. Canada also introduced a federal transfer payment program in 1957 to reduce the differences in revenue-generating capacity across Canada's ten provinces by compensating poorer provinces for their relatively weak tax bases or resource endowments. The program, known as equalization payments, has helped to ensure that Canadians, regardless of where they reside, have access to a reasonably similar level of provincial government services at reasonably similar levels of taxation. ${ }^{34}$ These policies were all implemented in the name of creating a sense of belonging and achieving national unity, but by the late 1960s, even that approach had failed to achieve national unity. The Province of Quebec - the target of most measures to forge a new national identity - began to demand special status that would recognize its differences from the other nine provinces. Quebec never saw Confederation as a compact between ten provinces but as one between French-speaking Quebec and English-speaking Canada. Canadians not included in the two founding nations also began to demand recognition.

\footnotetext{
34 Jim Feehan, "Canada's Equalization Formula: Peering Inside the Black Box... and Beyond," SPP Research Papers Vol. 7, Issue 24 (Calgary: The School of Public Policy, 2014), https://www.policyschool.ca/wp-content/uploads/2016/03/feehan-equalization.pdf.
} 


\section{Multiculturalism and a Sense of Belonging after the 1960s}

There began by the late 1960 s, then, a third approach to create a sense of belonging and to achieve national unity. It involved a series of policies to change the historical narrative from a French-English dichotomy to one that would transcend historical animosities and divisions to create a multicultural and more diverse community that embraced the ideals of a liberal political order. Canadian citizenship - and Canada itself as a distinctive nation - was to be defined as a civic nation that embraced the liberal ideals of multiculturalism, diversity, and individual rights. The old nationalism based primarily on two dominant cultures was declared too divisive as it had led not only to the fragmentation of Canada but also to its possible disintegration. ${ }^{35}$ The new approach embraced a civic rather than an ethnically-based nationalism where citizens were bound together by their collective belief in the equality of all through a set of shared rights. New Canadians - and, indeed, all Canadians - had to think about themselves, first and foremost, as rights-bearers, not as French, English or Aboriginal citizens of a national community. Recognizing cultural differences and a sense of belonging became a matter of rights.

This particular approach to fostering social cohesion and a sense of belonging was promoted more vociferously by Pierre Trudeau who became prime minister in 1968 and remained so until 1984. He believed there should be no special status for anyone, that a strong national government should legislate for all Canadians, and that Canada was a nation based on common and shared rights. In doing so, he attempted to redefine and strengthen the national narrative, creating a civic nationalism that would replace all forms of ethnic nationalism based primarily on a shared language, culture, and heritage - or what Michael Ignatieff has called "blood." 36 Civic nationalism was an attempt to replace ethnicity as the defining national characteristic with a new political society based on a philosophical vision around liberal individualism as the organizing principle for the nation-state. With the emphasis on civic nationalism, the state not only protected the individual from oppressive policies imposed by a democratically elected, majoritarian government but also gave agency to citizens. This meant they had "the ability as individuals to become self-actualizing - that is,

35 Andrew Nurse, "A Necessary Precondition: Michael Ignatieff and the Dilemmas of Civic Nationalism," in Beyond National Dreams: Essays on Canadian Citizenship and Nationalism, ed. Andrew Nurse and Raymond Blake (Toronto: Fitzhenry Whiteside, 2009), 31.

36 See Michael Ignatieff, Blood and Belonging: Journeys into the New Nationalism (Toronto: Penguin, 1993), 6. 
the ability as individuals to define their own identity, aspirations, and activities, rather than having them imposed." 37 Culture became an individual matter and the state's responsibility was to protect individual rights as each citizen carved out one's own cultural space. The state no longer promoted one culture or set of values over any other, but it privileged culture as a means of democratic participation. This type of rights philosophy, it was hoped, would create a new form of citizenship and attachment to the nation-state, as rights become the basis of the political community. 38

For Trudeau, Canada also promoted respect for cultural diversity and multiculturalism, which was a reversal of early government policies to assimilate immigrants and Indigenous peoples despite political leaders saying since 1867 that Canada made space for all groups. Canada introduced a policy of official multiculturalism in 1971, which ensured that all citizens in Canada could keep their identity and take pride in their particular heritage, but they had to do so through either the English or French language. Official multiculturalism meant that the state would not promote or privilege one culture over another; rather, all individuals had the right to maintain and celebrate their individual culture. Multiculturalism asked Canadians to accept all cultures and to realize that pluralism and ethnic diversity would strengthen - not threaten - the Canadian identity. It was, in some significant ways, an invocation of Cartier's 1867 dream for Canada. In 1982, Canada enshrined multiculturalism and a Charter of Rights and Freedom into its constitution, as part of the reconstruction of the Canadian ideal that recognized, celebrated and promoted a multicultural and diverse nation - an ideal that was embraced as progressive and enlightened and one, it was hoped, that would foster a strong attachment to Canada. ${ }^{39}$ With such an approach to citizenship and identity, Canadians were often told that Canadian diversity was no longer a problem that had to be managed but a strength that made their country an example to the world.

For a generation or more, liberal individualism, civic nationalism, and the promotion of diversity and multiculturalism were celebrated as the Canadian ideal, the normative approach to fostering a sense of belonging. Few contested the basic tenants of a national ideal that included such universal and liberal principles. Even so, many Canadians regretted what had been loss in the new national narrative. Much of Quebec insisted that Canada was neither a collection

\footnotetext{
${ }^{37}$ Nurse, “A Necessary Precondition,” 32.

38 Ibid., 33-34.

39 On this point see, Will Kymlicka and Wayne Norman, "Return of the Citizen: A Survey of Recent Work on Citizenship Theory," Ethics 104, No. 2 (1994): 352-381.
} 
of individuals nor a multicultural nation; it is two nations, one Francophone and one Anglophone, even if there was a clear embrace of the rights regime being promoted by Trudeau. Indigenous peoples and First Nations, which experienced their own renaissance in the 1950s and 1960s, could never accept that they were part of a multicultural (immigrant) community and fumed that their grievances were neither recognized nor settled under the rights paradigm. Apart from Quebec and Indigenous peoples, some Canadians complained about "hyphenated Canadians" and there emerged from the mid-1990s an accepted critique of the policy of multiculturalism and diversity and an increasing demand for the restoration of citizenship education in the public educational system as a way to create a shared sense of belonging. Among the most notable critics were Trinidadian-Canadian author, Neil Bissoondath, and former British Columbia premier, Ujjal Dosanjh. ${ }^{40}$ Questions were also raised about "reasonable accommodation," or, what the levels of accommodations would have to be provided for new immigrant communities. Some Canadians insisted the Charter of Rights and Freedoms, which brought in its train judicial activism and a preoccupation on rights, led to a clear imbalance between rights and responsibilities and served to undermine Canadian democracy. ${ }^{41}$ There emerged a "civic deficit," some contended, characterized by disputes by particular groups to defend their particular interests and by a lack of knowledge of democratic values, of civic responsibility, and of the responsibilities of citizenship. ${ }^{42}$ The political right was particularly critical as it lamented the breakdown of social cohesion and the weakening of traditional values: it saw the Canadian state in perpetual crisis divided by a collection of rival rights groups (LGBTQ+ versus heterosexual, Indigenous peoples versus non-Indigenous, French-speakers versus English-speakers, immigrants versus native-born, rural versus urban, and other points of cleavage) accentuated by the rejection of traditions and a national history, and a government that failed

${ }^{40}$ Christian Joppke, "The Retreat of Multiculturalism in the Liberal State: Theory and Policy," British Journal of Sociology 55, No. 2 (2004): 237-258, doi: 10.1111/j.1468-4446.2004.00017.x; Neil Bissoondath, Selling Illusions: The Cult of Multiculturalism (Toronto: Penguin, 1994). For a review of this literature, see Lloyd Wong, "Multiculturalism and Ethnic Pluralism in Sociology: An Analysis of the Fragmentation Position Discourse," Canadian Ethnic Studies 40, No. 1 (2008): 11-32, doi: 10.1353/ces.0.0066. A good overview of multiculturalism can be found in Yasmeen Abu-Laban and Christina Gabriel, Selling Diversity: Immigration, Multiculturalism, Employment Equity and Globalization (Peterborough: Broadview Press, 2002).

${ }^{41}$ Rainer Knopff and F. L. Morton, The Charter Revolution and the Court Party (Peterborough: Broadview, 2000); and William Gairdner, The Trouble with Canada (Toronto: Stoddart, 1990).

${ }^{42}$ William Galston, Liberal Purposes: Goods, Virtues and Duties in the Liberal State (Cambridge: Cambridge University Press, 1991), and Civics Expert Group (Australia), Whereas the People - Civics and Citizenship Education. Report (Canberra: Australian Government Publication Service, 1994). 
to defend traditional institutions and values that they believed necessary to provide stability and create a national community. Moreover, it was suggested, the right's revolution failed to eliminate the social and political fragmentation that had long marked Canada: it had not resulted in a unified national community nor a stronger sense of belonging. ${ }^{43}$ This fear or sense of crisis became particularly salient in the post-9/11 period and with the rise of terrorist groups which created a heightened sense of insecurity.

\section{National Values and Belonging in the New Millennium}

The next and fourth stage of the citizenship narrative has just passed. It was associated primarily with the Conservative government led by Stephen Harper. It was an approach that attempted to foster a sense of belonging and a national identity among an increasingly diverse population by promoting a set of shared values that the government claimed had emerged from Canada's history. It sought a new citizenship dream and hoped to eliminate the fragmentation that had beset Canada in the 1990s, marked mostly clearly by a second referendum on independence in Quebec and the heightened regional tensions across the country. It came with the hope of creating a greater sense of belonging among Canadians, national reconciliation, and the strengthening of national unity. It is sometimes overlooked that it was under Prime Minister Harper, on June 11, 2008, that the Truth and Reconciliation Commission was appointed to document the history and lasting impacts of the Canadian Indian Residential School system on Indigenous students and families and to bridge the divide with Indigenous peoples. The Commission was an essential element in Canada's apology to Indigenous people for residential schools and its disastrous legacies, and represented the hope for a "positive step in forging a new relationship between Aboriginal peoples and other Canadians," a relationship Harper said would be "based on the knowledge of our shared history, a respect for each other and a desire to move forward together with a renewed understanding that strong families, strong communities and vibrant cultures and traditions will contribute to a stronger Canada for all of us." ${ }^{44}$ Harper's new agenda might be seen as part of what has been described as "a renationalization trend" that aimed to provide a set of measures to promote

\footnotetext{
${ }^{43}$ Nurse, "A Necessary Precondition," 46; and Ignatieff, The Rights Revolution, 6.

44 "Prime Minister Harper offers full apology on behalf of Canadians for the Indian Residential Schools System," Department of Indigenous and Northern Affairs Canada, June 11, 2008, https:// www.aadnc-aandc.gc.ca/eng/1100100015644/1100100015649.
} 
the integration of newcomers and citizens and develop an inclusive understanding of national citizenship. ${ }^{45}$

Harper's approach to citizenship resulted in a rearticulation of the Canadian national narrative. It promoted a Pan-Canadian citizenship loosely based on the conservative values of loyalty, duty, tradition, and social stability which, the government contended, were necessary for the preservation of individual rights and liberties and the promotion of equity and justice which, collectively, he maintained would unite Canadians and establish a greater sense of belonging. ${ }^{46} \mathrm{Such}$ an approach to national identity and citizenship promised to eliminate fragmentation as each citizen had to see oneself, first and foremost, not as an individual but as a citizen of Canada who shared a common purpose that came from a shared set of social norms and ideals that embraces tolerance, compassion, community service and a devotion to pluralism. ${ }^{47}$ Rather than locating Canadian dynamism and the sense of belonging in individualism, diversity, individual rights and multiculturalism, the government insisted it was found in Canada's history and heritage, a strong military and a forceful foreign policy, a historical commitment to diversity, and its parliamentary system and symbols such as the Crown. ${ }^{48}$ Moreover, citizens were expected to embrace core cultural and legal traditions such as the rule of law, freedom of speech, the equality of all citizens, and a number of other precepts that made for an orderly and inclusive society. Those values emerged, Canadians were told, because of Canada's peculiar historical development and heritage.

Much of the new approach to citizenship was directed towards recent immigrants and embodied in Discover Canada: The Rights and Responsibilities of Citizenship, a new citizenship guide released in 2009. It claimed that Canada was a product of its history and had a strong national identity based on historical liberal-democratic values. ${ }^{49}$ Newcomers were expected to integrate into

45 See Dina Kiwan, "Human Rights and Citizenship: An Unjustifiable Conflation?" Journal of Philosophy of Education 39, No. 1 (2005): 37-50, doi: 10.1111/j.0309-8249.2005.00418.x.

46 See Canadian Citizenship: Sharing the Responsibility, a report in 1993 from the Standing Committee on Social Affairs, Science and Technology in the Canada Senate; and House of Commons Standing Committee on Citizenship and Immigration, Canadian Citizenship: A Sense of Belonging (Ottawa: Public Works and Government Services Canada, 1998).

47 Stephen Harper speech, April 24, 2010 and November 20, 2008.

48 Duane Bratt, "Mr. Harper Goes to War: Canada, Afghanistan, and the Return of 'High Politics' in Canadian Foreign Policy" (Paper presented at the Canadian Political Science Association Annual Conference, University of Saskatchewan, May 31, 2007), https://www.cpsa-acsp.ca/papers-2007 /Bratt.pdf.

${ }^{49}$ Discover Canada: The Rights and Responsibilities of Citizenship (Ottawa: Minister of Public Works and Government Services Canada, 2009), 3. 
mainstream Canadian society and develop a sense of attachment through their knowledge of Canada's history, its symbols, democratic institutions, geography, voting procedures, and the rights and responsibilities of citizenship..$^{50}$ Prospective citizens were told that they had rights but also responsibilities that "came from [Canada's] history and reflected shared traditions, identity and values." 51 It praised Canada's openness and tolerance, but reminded citizens that Canada's openness and generosity did not extend to barbaric cultural practices that tolerate spousal abuse, "honor killings," female genital mutilation or other gender-based violence. Moreover, those guilty of such crimes are severely punished under Canada's criminal laws. ${ }^{52}$

A knowledge of Canada's history was seen as very important in creating a sense of belonging, and the new approach to citizenship, not surprisingly, emphasized the importance of knowing Canada's rich history. From it, citizens would understand the commitment to ethnic diversity and pluralism as immigration and diversity had always been essential to the Canadian well-being and, accommodating diversity, historically central to the Canadian narrative. Newcomers to Canada had bonded together historically, the government maintained, in a common quest for prosperity, freedom, democracy, human rights, rule of law, and opportunity rather than through the privileging of the individual. Moreover, history is instructive and through it, Canadians could discover a better way to build the country. As such, it was essential, Harper often insisted, to recognize the past wrongs done by Canada and its governments, such as the Chinese Head Tax imposed upon Chinese immigrants from 1885 to 1923, and the treatment of Aboriginal children in residential schools. "One of our greatest strengths as Canadians is that we learn from history," Harper said, "and we are not enslaved by it." We must be "history's benefactors instead of its prisoners." ${ }^{33}$ Knowing Canada's history and heritage became essential for Canadian citizenship and fostering a greater sense of belonging.

This approach to creating national identity and a sense of belonging never attacked Canada's multiculturalism and diversity in the same way political leaders in Europe and elsewhere did during that period. Moreover, in Canada immigration and multiculturalism did not become ballot box issues and it escaped the so-called clash of civilizations which caused such strife in Europe and, later, in the United States under President Donald Trump. Yet, like all approaches

\footnotetext{
${ }^{50}$ Ibid., 3.

51 Ibid., 8.

52 Ibid., 9.

${ }^{53}$ Stephen Harper speech, February 7, 2010.
} 
to citizenship and national identity, Harper's was political and contested. It assumed that Canada was held together at some point in the past through a set of shared values, but aside from its commitment to the basic precepts of a liberal democracy, there is little evidence that a core set of shared values ever created among Canadians the sense of belonging. From the time of Confederation in 1867 , it was never assumed that citizens shared the same values. Rather, it was hoped that Canada's political institutions and its constitutional declarations permitted all communities to participate and flourish in the civic and political life of the nation, often on their own terms.

Harper's approach to citizenship was criticized for many reasons. It omitted many national accomplishments, especially those that came under Liberal administrations, notably, Canada's peacekeeping history and its role in crafting the UN Universal Declaration of Human Rights, Pierre Trudeau's role in repatriating the Constitution and achieving the Charter of Rights and Freedoms in 1982, Lester Pearson's adoption of the Canadian flag, and Mackenzie King's record as Canada's longest serving prime minister ${ }^{54}$ Critics also said Harper was trying to reclaim for Canada a conservative ideology by emphasizing the military, the royal family, the word "dominion," heroes and hockey and ignoring progressive accomplishments with such social issues as same-sex marriage and abortion. Historian Margaret Conrad reflected this view when she described Harper's citizenship dreams as a "kind of throwback to the 1950s [...], a tough, manly country with military and sports heroes that are all men." It was a Canada, she said, which was less sympathetic with her personal sense of a progressive, forward-looking nation. ${ }^{55}$ One columnist described the approach as an "incremental step in the rebranding of Canada into a conservative country, full of people more inclined to vote Conservative." 56 Many academics condemned the new nationalism as creating "warrior Canada" especially when Harper announced \$28 million to commemorate the bicentennial of the War of 1812 and funds to mark the Diamond Jubilee of Queen Elizabeth in 2012. Both events generated considerable opposition, as did the government's decision to rebrand the Canadian Museum of Civilization as the Canadian Museum of History. ${ }^{57}$ When the Conservatives

${ }^{54}$ Rebekah, “Discover Canada: A New Guide for Prospective Citizens," Citizens for Public Justice, November 13, 2009, http://www.cpj.ca/en/profile/profile_name/Rebekah+Sears.

55 Joe Friesen and Bill Curry, The Globe and Mail, March 2, 2010; and Jane Taber, "Scott Brison decries 'Conservative revisionist history of Canada," The Globe and Mail, March 3, 2010.

56 John Ivison, "Liberals get a lesson on branding," National Post, November 12, 2009.

57 Ian McKay and Jamie Swift, Warrior Nation: Rebranding Canada in the Age of Anxiety (Toronto: Between The Lines, 2012); Jordon Press, "Plaques across Ottawa to honour Fathers of Confederation for Canada's 150th," CTV News, November 16, 2015, https://www.ctvnews.ca/canada 
raised fears about newcomers to Canada not adopting Canadian values, especially during the 2015 federal election campaign when they proposed setting up a police hotline to report on what they called "barbaric cultural practices," hoping to capitalize on the fears expressed in some polls, particularly in Quebec, of immigrants not sufficiently integrating into Canadian society, many Canadians considered such fear mongering as particularly troubling, even "un-Canadian." 58 The Conservative party's divisive anti-Muslim rhetoric angered many and the party was quickly turfed from office (although the defeat of the Harper Conservatives can be attributed to a number of factors). ${ }^{59}$ After nearly a decade in power and its insistence on the importance of inculcating citizens with core Canadian values, the Harper government lost the support of voters. In the meantime, the Liberal party, under the leadership of Justin Trudeau, began offering a new way of narrating Canada, creating a sense of belonging among all Canadians based on diversity that had been a prominent narrative since the country's founding in 1867.

\section{Justin Trudeau and a Return to the Rhetoric of Diversity, 2015}

Trudeau attempted to "rebrand" Canada as an enlightened and progressive nation amid a world of rising populism of the right that often rallied against minorities and immigrant communities, and he hoped to do so with a renewed emphasis on diversity. Diversity, he insisted, is Canada's greatest strength, a foundational Canadian value and core to the collective Canadian identity. Like other prime ministers, Trudeau has said that Canada has learned how to be strong, not in spite of its differences, but because of them. His first major speech, given at the Office of the Canadian High Commissioner in London, just days after taking office, was titled "Diversity is Canada's strength." Echoing the words of Cartier from the 1860s, Trudeau said, “diversity isn't a challenge to be overcome or a difficulty to be tolerated. Rather, it's a tremendous source of strength. [...] We know that Canada has succeeded - culturally, politically, economically - because of our diversity, not in spite of it." And, as Canada's prime ministers

/plaques-across-ottawa-to-honour-fathers-of-confederation-for-canada-s-150th-1.2660057; and Yves Frenette, "Conscripting Canada's Past: The Harper Government and the Politics of Memory," Canadian Journal of History 49, No. 1 (2014): 49-65.

58 John Barber, "Canada's Conservatives vow to create 'barbaric cultural practices' hotline," The Guardian, October 2, 2015, https://www.theguardian.com/world/2015/oct/02/canada-conservatives -barbaric-cultural-practices-hotline.

${ }^{59}$ Andrew Potter, "Canada has never had shared values," Ottawa Citizen, December 22, 2011. 
had done since the early twentieth century, Trudeau, too, claimed that "Canada can also export the ideas and institutions that make diversity work so well at home. We know how to govern in a way," he said, "that is inclusive, transparent, respectful and effective, [and] we can share that expertise with other countries and their citizens." ${ }^{60}$ Yet, unlike previous prime ministers who also recognized Canada's diversity and insisted that all Canadians share a common commitment to citizenship values, Trudeau talked mainly of an "inclusive diversity" to overcome intolerance, radicalism and hate. ${ }^{61}$ He later told the The New York Times that Canada is becoming a new kind of country, not defined by our history or European national origins, but by a "pan-cultural heritage." "There is no core identity, no mainstream in Canada," he added: Canada is "the first post-national state." Even The New York Times called the suggestion "radical." 62

For Trudeau, diversity is the basis of all things Canadian and the only way to build social cohesion and foster a sense of belonging. He has also used diversity as a way to rebrand Canada from a resource-based economy to an intellectual one, hoping that the diversity "brand" will secure further international investment in Canada. "Diversity isn't just sound social policy," he said; "it is the engine of invention." At the 2016 World Economic Forum, Trudeau cited Canada's diversity as a key reason for its current and long-term success in the field of innovation and technology. It uniquely qualified Canada to address global crises such as climate change, he remarked; it is the greatest resource Canada has to offer to the world. ${ }^{63}$

Although Trudeau survived - just barely - when his government sought reelection in October 2019, it is too early to gauge how Trudeau's insistence on diversity will turn out and how it will impact the sense of belonging among Canadians. Trudeau has, however, politicized diversity as no other Canadian prime minister has since 1867 , and he seems to have used it as a wedge issue against those who hold different views on a variety of issues in Canada, ranging from abortion rights to immigration to confronting racism, even when his political opponents have committed themselves to maintaining Canada's law on a variety of social policies such as abortion. Yet, he has especially attempted

60 “Diversity is Canada's Strength," Justin Trudeau, Prime Minister of Canada, November 26, 2015, https://pm.gc.ca/en/news/speeches/2015/11/26/diversity-canadas-strength.

${ }^{61}$ See, for example, Tony Keller, “Justin Trudeau is Wrong: Diversity isn't Canada's Strength," The Globe and Mail, October 3, 2017, https://www.theglobeandmail.com/opinion/in-the-face-of-terror -unity-is-canadas-true-strength/article36462757.

62 “Trudeau's Canada, Again,” The New York Times Magazine, December 8, 2015.

63 "Canada is now an intellectual powerhouse, Justin Trudeau tells Davos," National Post, January 20, 2016. 
to define his major political rival, the Conservative party, and its supporters as being opposed to diversity and as social conservatives intent on limiting access to abortion, rolling back legislation on same-sex marriage, and bringing faith into the public policy even though Andrew Scheer, the admittedly hapless leader of the Conservative Party, has vowed not to tamper with any of those social issues. ${ }^{64}$ Such a politicization of diversity and the sense of belonging has the potential to polarize Canada around left-right ideologies, even if the trend says more about the choices that parties are offering voters than it does about the voters themselves and their attitudes. Canadians have decisively sent those politicians who wish to engage in divisive politics of culture and identity a very strong message. In her bid for the leadership of the Conservative Party which Scheer eventually won, Kellie Leitch, a former Conservative cabinet minister, promised a "Canadian values" test for newcomers which most Canadians - and Conservative supporters - dismissed "as dog-whistle tactics pandering to xenophobic and Islamophobic tendencies." 65 She won 7 percent of the vote and was dropped from the Conservative Shadow Cabinet by the new leader. Maxine Bernier who launched a new political party, The People's Party of Canada, after finishing second in the Conservative leadership contest, failed miserably in the 2019 general election. He had campaigned largely on an ideology of exclusionary, anti-immigrant nationalism and garnered only 1.7 percent of the popular vote, and failed to elect a single candidate from across Canada. He even lost his own constituency. ${ }^{66}$ The 2019 election showed that Canadians seem to have little appetite for political movements built on racial and ethnic exclusion that has been popular in other countries, even in the United States under Trump.

Yet, unlike his predecessors, Trudeau has not articulated a national identity and a sense of belonging beyond the embrace of the rhetoric of diversity. When asked what he means by diversity, he has mostly avoided giving specifics, preferring to go on the offensive, saying he can't believe that some Canadians still question diversity. Some people say, he has said, "People of different cultures and languages cannot live together harmoniously. Diversity means instability

64 “The Conservative Party has lost its way. It can't go back - it's time to forge a new path," The Globe and Mail, October 31, 2019, https://www.theglobeandmail.com/politics/article-the-conservative-party-has-lost-its-way-it-cant-go-back-its-time.

${ }^{65}$ Mira Sucharov, "How Kelly Leitch Poisoned Our National Dialogue," The Walrus, March 13, 2017.

${ }^{66}$ Jordan Stanger-Ross and Oliver Schmidtke, "Why the People's Party of Canada election result shouldn't be underestimated," CBC News Opinion, November 13, 2019, https://www.cbc.ca /news/opinion/opinion-peoples-party-of-canada-1.5351638. 
and insecurity. Diversity is dangerous. I don't believe any of that." ${ }^{67}$ Trudeau is trying hard to be progressive in his promotion of diversity, though one had to wonder if it is too much politics and too little policy; all play-acting and too little substance. He has been accused of "virtue signaling" as there has been significant gaps between his rhetoric and the policies he has pursued. Early in his tenure, he talked about protecting human rights but continued to sale Canadian-made light armored vehicle to Saudi Arabia, one of the world's most repressive regimes, and he was largely silent in late 2019 on Chinese treatment of protesters in Hong Kong. He advocates a feminist approach to foreign policy but hardly any new funds to support international aid while promising billions to rebuild the military. ${ }^{68}$ His diversity rhetoric has also been seriously challenged by several incidents. The first came when the media reported that Trudeau and his top advisors had exerted undue pressure on Jody Wilson-Raybould, Canada's first Indigenous attorney-general, to seek remediation rather than pursuing criminal prosecution for Quebec engineering giant SNC-Lavalin that was facing serious corruption charges. Trudeau wanted to avoid angering Quebecers at election time. When she refused, demotion to a minor portfolio followed, and she was later kicked out of the Liberal party along with Jane Philpott, another strong female minister who courageously supported Wilson-Raybould in her confrontation with Trudeau. The interference in criminal proceedings and the firing of two powerful women when they disagreed with him damaged Trudeau's claim to be a feminist. Wilson-Raybould's expulsion seriously weakened his insistence that he was committed to reconciliation and the ending of colonialism for Indigenous peoples. It was also revealed just as the 2019 campaign began that Trudeau had appeared on multiple occasions in brown and black-face, even as a 29-yearold teacher. Though he was particularly contrite in his apology, his progressive mantel was shattered. Still, with a large number of Canadians willing to forgive their prime minister for such actions when Trudeau himself had condemned politicians of more than a hundred years ago for their racism, people both inside and outside Canada wondered how committed Canada is to diversity and inclusion. ${ }^{69}$

67 "The Canadian Opportunity," Address by the Right Honourable Justin Trudeau, Prime Minister of Canada at Davos, Switzerland, January 20, 2016, https://pm.gc.ca/eng/news/2016/01/20/canadian-opportunity-address-right-honourable-justin-trudeau-prime-minister-canada.

68 Stephen Marche, "The Woke Will Always Break Your Heart: Canadian progressives have to decide whether they care more about Justin Trudeau's policy achievements or his offensive style," The Atlantic, October 3, 2019; John Robson, "How dare you virtue-signal, yet not stand with Hong Kong?" National Post, November 27, 2019.

${ }^{69}$ Janaya Khan, “Trudeau's Blackface Exposes the Truth Canada is no Racial Haven," CNN, September 21, 2019, https://www.cnn.com/2019/09/21/opinions/trudeau-blackface-canada-no-racial 
Trudeau has also been dogged with allegations that he groped a young female reporter in $2000 .{ }^{70}$ Trudeau's reelection might result in a more sincere approach to diversity and reconciliation in Canada but his actions are troubling for a nation that prides itself on its commitment to diversity.

\section{Citizenship Challenges Today}

Canada routinely ranks in the top tier of countries on various international indices that measure social, cultural and economic well-being around the world. In the 2019 U.S. News and World Report's "Best Countries" report, Canada was ranked third behind Switzerland and Japan. The survey was based on a series of 65 attributes, or factors, considered relevant to the success of any modern nation, and administered to 20,000 people across 80 countries. The attributes were grouped into nine sub-rankings, including, among others, quality of life, entrepreneurship, culture, and citizenship. Citizenship, which accounts for 16 percent of the overall ranking score, measures such attributes as how a country cares about human rights, the environment, gender equality, religious freedom, respect for property rights and how trustworthy it is and how well it distributes political power. Canada ranked second in this category behind only Norway. The U.S. News and World Report noted that Canada's "expansive wilderness plays a large role in Canadian identity, as does the country's reputation of welcoming immigrants." It also claimed that "Canadians pride themselves in encouraging all of their citizens to honor their own culture," adding that Canada adopted a national policy of multiculturalism in 1971 to celebrate its diversity. ${ }^{71}$

Throughout its history, Canada has faced few existential crises but it cannot be ignored that it has struggled with fostering a sense of belonging among its citizens since it was created more than 150 years ago. It was - and remains - a fragile construct and leaders have always had to act to ensure unity. For much of its recent past, the greatest threats to the sense of belonging have been in the province of Quebec which has demanded either special status or separation. It twice held referendums on sovereignty association or independence and the most recent, in 1995, came within 54,288 votes of sundering the Canadian nation.

\footnotetext{
-haven-khan/index.html.

${ }^{70}$ Ashifa Kassam, “Trudeau: I Apologized to Reporter Behind Groping Claim,” The Guardian, July 6, 2018, https://www.theguardian.com/world/2018/jul/06/trudeau-i-apologised-at-once-to -reporter-behind-groping-claim-canada-2000-music-festival.

71 “Overall Best Countries Ranking," U.S. News and World Report, January 23, 2019, https://www .usnews.com/news/best-countries/rankings-index.
} 
Although the urgency of addressing Quebec separatism has vanished, Canada remains a fragmented nation. As noted above, the disparity between Indigenous and non-Indigenous peoples remains a serious cause of division.

There are other serious challenges to notions of inclusive citizenship in Canada as well. While the issue of separation has largely disappeared, Quebec remains at the center of questions around inclusive citizenship in Canada. The Coalition Avenir Québec (CAQ), which was elected in October 2018, has vowed to reduce immigration by 24 percent and to expel immigrants who do not become proficient in French within three years and integrate into Quebec society by adopting Quebec values. ${ }^{72}$ Quebec further raised the stakes in the inclusive citizenship challenge when it ratified a "secularism law" (Bill 21) which forbids public employees in positions of authority, such as judges, prosecutors, police officers, prison guards and school teachers, from wearing religious symbols at work. The Québec solidaire, a social-democratic sovereigntist political party in Quebec, described such measures as "divisive" but Canada's major political parties in the 2019 general election largely refused to condemn Quebec's actions despite the fact that many Canadians and political analysts have raised major concerns about the new law; Canadians have come to expect their political leaders to defend diversity and condemn exclusionary laws that will divide Canadians. ${ }^{73}$ Yet, as prime minister, Trudeau, who promotes increased immigration as the key to a stronger economy and as emblematic of Canada's commitment to diversity, has promised to work with Premier François Legault to lower targets on immigration to Quebec. ${ }^{74}$ Even more troubling was Trudeau's back-tracking on the admission of refugees to Canada. In the wake of the American clampdown on refugees in 2017, he had tweeted "To those fleeing persecution, terror \& war, Canadians will welcome you, regardless of your faith. Diversity is our strength. Welcome to Canada." When thousands entered Canada at irregular border crossings, Trudeau dispatched his immigration minister to the United States to discourage people from coming to Canada except through regular entry points and

72 Chantel Hébert, "By campaigning to cut immigration, Quebec's opposition parties are playing politics with their province's future," Toronto Star, September 10, 2018.

73 Philip Authier, "Quebec minister for women stands by belief that hijabs are oppressive," Montreal Gazette, February 6, 2019. See also "2019 Federal Election Platform Guide: Where the Parties Stand on Everything," Maclean's, April 30, 2019.

${ }^{74}$ Bill Curry, "Trudeau offers to work with Legault on a temporary reduction in immigration levels," The Globe and Mail, January 17, 2019; and Daniel LeBlanc, "Ottawa rejects Quebec's call to impose conditions on would-be immigrants," The Globe and Mail, February 9, 2019. 
then introduced measures to make it more difficult for refugees to make claims in Canada. ${ }^{75}$

Yet, the threat to the sense of belonging in Canada currently is focused not in Quebec but in the western regions of the country, particularly in Alberta and Saskatchewan. The four western provinces of Manitoba, Saskatchewan, Alberta and British Columbia have long complained about how the Canadian federation does not work in their interests, and they have acquired considerable political and economic power to perhaps challenge the existing power dynamic in Canada. The region constitutes just under a third of Canada's population but is projected to reach more than 35 percent by 2036. The major issue currently in the West is pipelines, especially in carbon energy producing Alberta and Saskatchewan, where there has developed an entrenched view that the national government is not doing enough to help get their resources to market in the face of Indigenous and environmental opposition and that of the province of Quebec which of all of the ten provinces has downplayed the role of carbon-based energy in the Canadian economy. It has also resisted any attempt to move Western oil through its territory to refineries in Atlantic Canada. The Government of British Columbia also opposes the building of new pipelines which prompted a war of words with Alberta but the British Columbia Court of Appeal ruled in 2019 that the province could not impede or prevent the construction of a new pipeline. ${ }^{76}$ Indigenous communities throughout the west are divided on the construction of new pipelines with some bitterly opposed and others eager to participate, including working together to purchase from the Government of Canada the Trans Mountain pipeline. ${ }^{77}$ There is growing discontent in the Canadian West and it might be serious, especially as much of the country is worried about the impact of oil and gas on climate change and does not favor expansion in the sector. A recent survey found two-thirds (66\%) of respondents in the West not only believe that their region has been treated unfairly by the federal government, but they also believe the treatment has been worsening in recent years. ${ }^{78}$ Only

\footnotetext{
75 Ashifa Kassam, “Trudeau forced to backtrack on open invitation to refugees," The Guardian, August 25, 2017, https://www.theguardian.com/world/2017/aug/25/justin-trudeau-forced-tobacktrack-on-open-invitation-to-refugees; and Andrew Coyne, "In two years, Liberals go from \#WelcomeToCanada to deportations without hearings," National Post, April 12, 2019.

76 "B.C. Court Tells Province to Reconsider Environmental Approval of Trans Mountain Pipeline Extension," The Globe and Mail, September 18, 2019.

77 "Anti-pipeline accord could deepen divide in indigenous communities," The Globe and Mail, May $16,2018$.

78 Western alienation, the term often given to the disaffection of Western Canada, was particularly acute in the 1980s and 1990s, and led to the creation of the Reform Party of Canada, which won
} 
30 percent of Western Canadians say the federal government in Ottawa reflects and represents their province well, and substantial majorities in the four Western provinces want their provincial governments to take a hard line when dealing with the national government, though there remain vast differences between southern and urban British Columbia and Alberta and Saskatchewan. It is noteworthy, too, that residents of Alberta, Saskatchewan and British Columbia are more likely to think of themselves as Albertans, Saskatchewanians and British Columbians, respectively, than Canadians, and they believe they do not get the respect they deserve from other Canadians. ${ }^{79}$ The sense of alienation was demonstrated clearly in the 2019 federal election when the governing Liberal Party loss half of its seats in Western Canada and failed to win a single seat in Saskatchewan and Alberta. With days of the election, a separatist group calling itself Wexit Alberta applied for federal political party status. A new Ipsos poll showed a historic high level of interest in secession from Canada in both Alberta (33 percent) and Saskatchewan (27 percent). ${ }^{80}$

\section{Conclusion}

The acceptance of diversity as a way of fostering a sense of belonging and embracing diverse communities was evident in the discourse and in the constitutional arrangements made in 1867 when Canada was created, and it has remained as the basis of Canadian national identity. Although the Canadian state has not always embraced diversity in its policies and orientations, it has throughout its history rhetorically called upon its established political communities and citizens of multiple political identities to work together and create a national narrative that allows everyone to share in the great arch of national destiny. The various national narratives and identities that have been promoted since 1867 were each designed to unite Canadians to not only sustain the nation but to build a better one and create a stronger sense of belonging. Each of the successive citizenship dreams has come with the hope that it can build an inclusive citizenship among

many of the constituencies west of Ontario in 1993 and in 1997, became the official opposition in Parliament. In 2003, it merged with the Progressive Conservative Party to create a new Conservative Party which formed the government in 2006. See, for instance, David Laycock, "Populism and democracy in Canada's Reform Party," in Populism in Europe and the Americas: Threat or Corrective for Democracy? ed. Cas Mudde and Cristóbal Rovira Kaltwasser (Cambridge: Cambridge University Press, 2012), 46-67.

79 "What unites \& defines the 'West'? In a complicated confederation, less than one might think," Angus Reid Institute, January 30, 2019, http://angusreid.org/new-west-western-identity.

80 "Ipsos poll on Western separation records historic highs," Global News, November 6, 2019. 
a diverse population. At the heart of Canadian citizenship, then, has been the dream that diverse communities can work together to create a cohesive nation. Canada has long scorned the notion of one citizenship because such an approach would invariably lead to political splintering and perhaps the sundering of the nation, and notions of citizenship and the Canadian narratives have changed several times since 1867 in hopes of finding a narrative that can achieve political stability and foster a better sense of belonging. Even so, Canada remains a fragile construct as the recent 2019 general election revealed.

The current approach to national solidarity centers on notions of diversity as it did in 1867. Diversity is progressive and good, but diversity has become about more than one's skin color or gender. Diversity brings with it colliding values, norms, and ideas, and the challenge ahead for Canada's leaders - and citizens more generally - is how they might embrace and encourage all forms of diversity. There is reason to be hopeful that the creation of a narrative of diversity can be sustained as three-quarters of Canadians see diversity and multiculturalism as cornerstones of the Canadian identity and are proud that Canada is a multicultural society. However, roughly the same percentage agrees that newcomers are not adopting Canadian values. Recent polls suggest that many Canadians believe there should be limits to how accommodating the country should be to immigrants. ${ }^{81}$ Perhaps diversity and multiculturalism have gone from a twentieth century dream to a twenty-first century conundrum. ${ }^{82}$ In Quebec there is particular concern about the weakening of the French language and culture in the face of increasing immigration. Elsewhere in the country, political leaders are struggling with finding a balance between multiculturalism and economic integration and the fostering of a sense of belonging. Today, the rise of right-wing populism, the fragmentation along regional and urban-rural lines, and the resistance to Trudeau's diversity agenda, especially in Quebec, are further reasons to be concerned. Yet, the commitment to diversity has a long history in Canada and that history should serve the country well in the troubling times that might lie ahead.

81 "Multiculturalism is our Identity," The Globe and Mail, April 27, 2018; and An Environics poll in 2006 found that 65 percent of Canadians agreed with the statement "Too many immigrants do not adopt Canadian values." See, Michael Adams, "John Tory: Well beyond the Bland," The Globe and Mail, September 17, 2007.

${ }^{82}$ Allan Gregg, "Multiculturalism: A Twentieth-Century Dream became a Twenty-First Century conundrum," The Walrus, March 12, 2006. 